\title{
ANALISIS FAKTOR - FAKTOR YANG BERPENGARUH TERHADAP PROFITABILITAS PERBANKAN YANG GO PUBLIC DI BURSA EFEK INDONESIA PADA TAHUN 2012 - 2016
}

\begin{abstract}
Astohar
Dosen Tetap STIE Totalwin Semarang

Email: astohardemak@gmail.com

Keywords: Abstrak

CAR, NPL, LDR, Banking plays a role in economic development, namely in spurring BOPO, NIM dan ROA economic growth. The main function of the bank is as a financial intermediary from parties who have excess funds with those who lack funds. The existence of the banking sector has an important role, which in the life of the community mostly involves services from the banking sector. Banking profitability is a ratio to determine the financial performance of banks. Research from Ali and Laksono (2017) is still interesting to develop both the variables and the object of research. In this study, the variable capital adequacy ratio (CAR) added with consideration that there were still differences between researchers.

This study took the object of banks going public on the Indonesia Stock Exchange. Banks that went public in 2016 were 43 banks. After checking as many as 26 banks that can be taken as samples through purposive random sampling technique. 17 banks that cannot be used as samples include going public in the year after 2012 and the absence of complete data. The analytical tool used is multiple regression equation test with the requirement to meet normal criteria and no classical assumption deviations occur.

The results showed that the capital adequacy ratio (CAR), loan to deposit ratio (LDR), operational costs and operating income (BOPO) proved to have a negative and significant influence on banking profitability. Net interest margin (NIM) is proven to have a positive and significant influence on banking profitability. Nonperforming loans (NPLs) are proven to have a negative and insignificant effect on banking profitability. Large variations in capital structure variables in banks that go public in Indonesia can be explained by variations in the variables of capital adequacy ratio $(C A R)$, non-performing loans (NPL), loan to deposit ratio $(L D R)$, operational costs and operating income (BOPO), net interest margin (NIM) is $92.3 \%$.
\end{abstract}




\section{PENDAHULUAN}

Peran perbankan dalam perkembangan ekonomi sangat penting untuk memacu pertumbuhan perekonomian. Hal ini disebabkan perbankan mempunyai fungsi utama sebagai perantara keuangan (financial intermediary) dari pihak yang memiliki kelebihan dana (surplus) dengan pihak yang kekurangan dana (defisit) (Nusantara, 2009. Perbankan merupakan lembaga keuangan yang memiliki peranan dalam sistem keuangan di Indonesia. Keberadaan sektor perbankan memiliki peranan cukup penting, dimana dalam kehidupan masyarakat sebagian besar melibatkan jasa dari sektor perbankan (Putrianingsih dan Yulianto, 2016).

Sebagai lembaga keuangan yang mengedepankan kepercayaan dan jasa maka bank berusaha sebanyak mungkin menarik nasabah baru ataupun investor. Hal ini dimaksudkan untuk memperbesar dananya dan juga memperbesar pemberian kredit dan jasanya. Peran bank menjadi strategis dengan tetap menjaga kesehatan dan stabilitas perbankan (Veithzal, dkk, 2007). Perbankan yang sehat merupakan kebutuhan suatu perekonomian yang ingin tumbuh dan berkembang dengan baik. Fungsi intermediasi perbankan setelah terjadinya krisis perbankan di Indonesia telah mengakibatkan lambannya kegiatan investasi dan pertumbuhan ekonomi (Defri, 2012).

Selain berperan penting pada perekonoian, industri perbankan merupakan industri yang syarat dengan risiko, terutama karena melibatkan pengelolaan uang masyarakat dan diputar dalam bentuk berbagai investasi, seperti pemberian kredit, pembelian surat-surat berharga dan penanaman dana lainnya (Ghozali, 2007).
Kondisi perbankan di Indonesia selama ini merupakan periode yang banyak dinamika bagi industri perbankan nasional. Ditengah beratnya tantangan yang dihadapi, bank pada umumnya mampu mempertahankan kinerja positif. Profitabilitas, likuiditas dan solvabilitas bank stabil pada tingkat yang memadai. Fungsi intermediasi masih kendala akibat perubahan kondisi perekonomian yang kurang menguntungkan (Muslem dan Chabachib, 2016)

Saat ini perbankan di Indonesia memasuki masa persaingan yang sangat kompetitif.Hal ini disebabkan banyaknya bank yang beroperasi di Indonesia baik yang beroperasi secara lokal maupun yang beroperasi berskala internasional. Dengan semakin kompetitifnya persaingan di dunia perbankan maka bank-bank mulai meningkatkan keunggulan kompotetitifnya untuk memberikan layanan yang terbaik kepada para nasabahnya melalui berbagai macam produk perbankan seperti produk dana, produk pinjaman atau produk jasa lainnya (Rahmani, 2017).

Kinerja keuangan perbankan atau kesehatan perbankan dapat dilihat melalui kinerja profitabilitas. Faktor-faktor yang mempengaruhi profitabilitas bank dapat bersumber dari berbagai kinerja profitabilitas yang ditunjukkan beberapa indikator. Menurut Bank Indonesia rasio profitabilitas yang penting bagi bank adalah (ROA) (Latifah dkk, 2012). Return on asset (ROA) digunakan untuk mengukur profitabilitas bank, karena Bank Indonesia sebagai pembina dan pengawas perbankan lebih mengutamakan nilai profitabilitas suatu bank yang diukur dengan aset yang dananya sebagian besar dari dana simpanan masyarakat. Semakin besar ROA suatu bank, semakin besar pula tingkat 
keuntungan yang dicapai bank, dan semakin baik posisi bank tersebut dari segi penggunaan asset (Astohar, 2016).

(ROA) memfokuskan kemampuan perusahaan untuk memperoleh earning dalam operasi perusahaan, sedangkan Return On Equity (ROE) hanya mengukur return yang diperoleh dari investasi pemilik perusahaan dalam bisnis tersebut (Marwadi, 2005), sehingga dalam penilitian ini ROA digunakan sebagai ukuran kinerja perbankan. ROA merupakan rasio antara laba sebelum pajak terhadap total asset. semakin besar ROA menunjukan kinerja semakin baik, karena tingkat pengembalian (return) semakin besar. Apabila ROA meningkat, berarti profitabilitas perusahaan meningkat, sehingga dampak akhirnya adalah peningkatan profitabilitas yang dinikmati oleh pemegang saham (Husnan, 2012).

Menurut Kuncoro dan Suhardjono (2005) dalam (Khoirunisa, 2016), bank yang baik ditandai dengan tingkat tingkat profitabilitas yang tinggi, mampu membagikan deviden dengan baik, prospek usaha yang selaluberkembang, dan dapat memenuhi ketentuan prudential banking regulation dengan baik. $s$ (ROA) yang positif menunjukkan bahwa dari total aktiva yang dipergunakan untuk beroperasi, perusahaan mampu memberikan laba bagi perusahaan. Sebaliknya apabila $s$ yang negatif menunjukkan bahwa dari total aktiva yang dipergunakan, perusahaan mendapatkan kerugian. Jadi jika suatu perusahaan mempunyai ROA yang tinggi maka perusahaan tersebut berpeluang besar dalam meningkatkan pertumbuhan. Tetapi jika total aktiva yang digunakan perusahaan tidak memberikan laba maka perusahaan akan mengalami kerugian dan akan menghambat pertumbuhan (Simanjutak, 2016).

Return on asset (ROA) dikatakan penting bagi bank karena untuk mengukur efektivitas perusahaan didalam menghasilkan keuntungan dengan memanfaatkan aktiva yang dimilikinya. Return on asset (ROA) merupakan rasio antara laba sesudah pajak tehadap total asset. Banyak fakor yang mempengaruhi profitabilitas dimana profitabilitas merupakan kemampuan bank untuk menghasilkan laba secara efektif dan efisien (Ali dan Laksono, 2017). Factor - factor tersebut seperti non performing loan (NPL), loan to deposit ratio (LDR), biaya operasional dan pendapatan operasional (BOPO) serta net interest margin (NIM) (Ali dan Laksono, 2017).

Permasalahan dalam penelitian ini adalah menyempurnakan penelitian dari Ali dan Laksono (2017) dengan menambah variable capital adequacy ratio (CAR) juga mempunyai dampak terhadap profitabilitas bank (Khoirunisa dkk, 2016). Variable capital adequacy ratio (CAR) dipilih karena variable ini masih terjadi perdebatan dalam mempengaruhi profitabilitas. Menurut Bernadin (2016) rasio kecukupan modal berpengaruh positif terhadap profitabilitas yang didukung oleh Rahmani (2017) peningkatan capital adequacy ratio (CAR) dapat meningkatkan profitabilitas. Hasil yang berbeda dari (Candra, 2013) yang mana peningkatan capital adequacy ratio $(C A R)$ justru menurunkan profitabilitas perbankan.

\section{Telaah Pustaka}

\section{Anticipated Income Theory}

Perbankan didorong agar lebih agresif dalam memberikan kredit yang 
berjangka panjang. Perbankan seharusnya dapat memberikan kredit jangka panjang, dimana cicilan pokok pinjaman dan bunga (bagi hasil bank syariah) dapat diharapkan dan dijadwalkan pembayarannya sesuai dengan jangka waktu yang telah ditetapkan. Para bankir kembali mulai melihat portofolio pinjaman mereka sebagai sumber likuiditas. Teori pendapatan mendorong para bankir untuk memperlakukan pinjaman jangka panjang sebagai sumber likuiditas potensial. Bankir menganggap pinjaman hipotek sebagai sumber likuiditas bila biasanya jatuh tempo lebih cepat. Portofolio pinjaman bank menyediakan aliran dana terus menerus yang terus berlanjut ke bank likuiditas. Meskipun pinjaman dalam jangka panjang, likuiditas bank tetap terjaga.

Teori antisipasi pendapatan mendalilkan bahwa likuiditas bank dapat dikelola melalui pengaturan dan penataan komitmen pinjaman yang dibuat oleh bank kepada nasabah. Likuiditas dapat direncanakan jika pelunasan pinjaman yang dijadwalkan oleh pelanggan didasarkan pada masa depan peminjam individual. Teori ini memberikan penekanan lebih pada potensi pendapatan dan kelayakan kredit peminjam sebagai jaminan terbesar untuk memastikan likuiditas yang memadai (Nzotta, 2004, dalam Olarewaju dan Adeyemi, 2015)

\section{Profitabilitas}

Profitabilitas bank merupakan suatu kemampuan bank dalam menghasilkan laba dengan memanfaatkan aktiva yang dimiliki dakan dalam suatu periode (Riyadi, 2006, dalam Astohar, 2016). Profitabilitas (profitability) atau diproksi dengan ROA adalah kemampuan suatu bank dalam memperoleh laba. menurut Bank Indonesia,
(ROA) merupakan perbandingan antara laba setelah pajak dengan total asset dalam satu periode. ROA digunakan untuk mengukur kemampuan manajemen bank dalam memperoleh keuntungan (laba sebelum pajak) yang dihasilkan dari ratarata total aset bank yang bersangkutan. Semakin besar ROA, semakin besar pula keuntungan yang dicapai perbankan sehingga kemungkinan suatu bank dalam kondisi bermasalah semakin kecil. Laba sebelum pajak adalah laba bersih dari kegiatan operasional sebelum pajak. Sedangkan rata-rata total aset adalah volume usaha atau aktiva (Luciana dan Winni, 2005)

$s$ (ROA) adalah perbandingan antara laba bank dengan total aktiva (Dendawijaya, 2005). ROA menunjukkan kemampuan manajemen bank dalam menghasilkan income dari pengelolaan aset yang dimiliki (Kuncoro dan Suhardjono, 2011:505). Semakin besar ROA maka kondisi bank akan semakin baik. (ROA) atau hasil pengembalian atas aset merupakan rasio yang menunjukkan hasil atas penggunaan aset perusahaan dalam menciptakana laba bersih, dengan kata lain rasio ini digunakan untuk mengukur seberapa besar jumlah laba bersih yang akan dihasilkan dari setiap rupiah dana yang tertanam dalam total aset (Hery 2015).

\section{Capital Adequacy Ratio}

Capital adequacy ratio merupakan rasio kinerja bank untuk mengukur kecukupan modal yang dimiliki bank untuk menunjang aktiva yang mengandung atau menghasilkan resiko. CAR menjadi rasio kecukupan modal yang berfungsi menampung risiko kerugian yang kemungkinan dihadapi oleh bank. Semakin tinggi CAR, maka semakin baik 
kemampuan bank tersebut untuk menanggung risiko dari setiap kredit / aktiva produktif yang berisiko tertimbang (Rahmani, 2017). Capital adequacy ratio (CAR) adalah rasio kinerja bank untuk mengukur kecukupan modal yang dimilki bank untuk menunjang aktiva yang mengandung atau mengahasilkan resiko, misalnya kredit yang diberikan (Dendawijaya, 2005).

Semakin tinggi resiko rasio CAR maka semakin baik kondisi suatu bank dan jika nila CAR tinggi berarti bank tersebut mampu membiayai kegiatan operasinya. Tingginya CAR mengindikasikan bahwa bank tersebut mampu membiayai kegiatan operasional dan memberikan kontribusi yang cukup besar bagi profitabilitas (Kuncoro et al. 2002). Hal berbeda ditunjukkan oleh Khoirunisa (2016) yang mana hasil penelitian menunjukan bahwa capital adequacy ratio (CAR) tidak berdampak terhadap profitabilitas bank, yaitu kenaikan dari CAR tidak serta merta meningkatkan profitabilitas bank. Lebih lanjut hasil penelitian dari Candra (2013) menunjukkan bahwa peningkatan capital adequacy ratio (CAR) justru menurunkan profitabilitas perbankan. Berdasarkan argument peneliti diatas dapat ditarik hipotesis 1 sebagai berikut :

$\mathrm{H}_{1}$ : capital adequacy ratio modal berpengaruh negative dan signifikan terhadap profitabilitas perbankan

\section{Non Performing Loan (NPL)}

\section{Non performing loan (NPL)} menunjukkan kemampuan manajemen bank dalam mengelola kredit bermasalah yang diberikan oleh bank. Apabila suatu bank kondisi NPL tinggi maka akan memperbesar biaya lainnya, sehingga berpotensi terhadap kerugian bank
(Mawardi, 2005). Semakin tinggi rasio NPL maka semakin buruk kualitas kredit yang menyebabkan jumlah kredit bermasalah semakin besar sehingga dapat menyebabkan kemungkinan suatu bank dalam kondisi bermasalah semakin besar. Setelah kredit diberikan, bank wajib melakukan pemantauan terhadap penggunaan kredit serta kemampuan dan kepatuhan debitur dalam memenuhi kewajiban.

non perfoming loan (NPL) yang tinggi akan memperbesar biaya, sehingga berpotensi terhadap kerugian bank. Semakin tinggi rasio ini amka akan semakin buruk kualitas kredit bank yang menyebabkan jumlah kredit bermasalah semakin besar (Samsara, 2016). Maka dalam hal ini semakin tinggi rasio NPL maka semakin rendah profitabilitas suatu bank. Lebih lanjut Muslem dan Chabachib (2016) serta Aprilya (2017) yang memberikan hasil bahwa non performing loan (NPL) berpengaruh negative terhadap profitbilitas. Berdasarkan argument tersebut dapat dirumuskan hipotesis kedua $\left(\mathrm{H}_{2}\right)$ sebagai berikut :

$\mathrm{H}_{2}$ : non performing loan mempunyai pengaruh yang negative dan signifikan terhadap return on asset (ROA)

\section{Loan to Deposit Ratio (LDR)}

Loan to deposit ratio (LDR) adalah perbandingan antara kredit yang diberikan dengan dana pihak ketiga (giro, tabungan, deposito, dan kewajiban jangka pendek lainnya). LDR ini menjadi salah satu tolok ukur likuiditas bank yang berjangka waktu agak panjang. Semakin tinggi LDR menunjukkan semakin jelek kondisi likuiditas bank,

karena penempatan pada kredit juga dibiayai dari dana pihak ketiga yang 
sewaktu-waktu ditarik (Simanjutak, 2016).

Loan Deposit Ratio (LDR) yaitu menunjukkan kemampuan suatu bank di dalam menyediakan dana kepada debiturnya dengan modal yang dimiliki oleh bank maupun dana yang dapat dikumpulkan oleh masyarakat. Menurut Achmad (2003)

Peningkatan loan to deposit ratio (LDR) menunjukkan kurangnya efektifitas bank dalam menyalurkan kredit sehingga hilangnya kesempatan bank untuk memperoleh laba (Sudarmawati dan Pramono (2017). Hal ini menunjukkan bahwa loan to deposit ratio yang tinggi menunjukkan kredit yang diberikan kepada masyarkaat atau nasabah adalah lebih besar dari dana pihak ketiga yang diterima, hal ini berdampak pada kemungkinan peningkatan risiko dan dampaknya adalah justru akan menurunkan profitabilitas bank (Ali dan Laksono, 201\&). Berdasarkan argument tersebut dapat dirumuskan hipotesis kedua $\left(\mathrm{H}_{3}\right)$ sebagai berikut :

$\mathrm{H}_{3}$ : loan to deposit ratio (LDR) mempunyai pengaruh yang negative dan signifikan terhadap return on asset (ROA)

\section{Biaya Operasional dan Pendapatan Operasional (BOPO)}

Biaya operasional digunakan untuk mengukur tingkat efisien dan kemampuan bank dalam melakukan kegiatan operasionalnya. Biaya operasional merupakan biaya yang dikeluarkan oleh bank dalam rangka menjalankan aktivitas usaha pokoknya (seperti biaya bunga, biaya tenaga kerja, biaya pemasaran dan biaya operasi lainnya).pendapatan operasional merupakan pendapatan utama bank, yaitu pendapatan bunga yang diperoleh dari penempatan dana dalam bentuk kredit dan pendapatan operasi lainnya. Semakin kecil rasio ini berarti semakin efisien biaya operasional yang dikeluarkan bank yang bersangkutan sehingga kemungkinan suatu bank dalam kondisi bermasalah semakin kecil (Sudamawati dan Pramono, 2017).

Hasil penelitian dari Defri (2012) menunjukkan bahwa biaya operasional dan pendapatan operasional (BOPO) mempunyai pengaruh yang negative terhadap profitabilitas. Hal ini menunjukkan bahwa tingginya biaya operasional akan berdampak pada turunnya pendapatan, sehingga menurunkan stabilitas perbankan (Martindas dkk, 2013). Hal yang sama ditemukan oleh Khoirunisa (2016) serta Ali dan Laksono (2017) bahwa variabel efisiensi operasi yang diproksikan dengan BOPO berpengaruh negatif terhadap kinerja perbankan yang diproksikan dengan Return on Assets (ROA). Berdasarkan argument tersebut dapat dirumuskan hipotesis kedua $\left(\mathrm{H}_{4}\right)$ sebagai berikut :

$\mathrm{H}_{4}$ : $\mathrm{BOPO}$ mempunyai pengaruh yang negative dan signifikan terhadap return on asset (ROA)

\section{Net Income Margin (NIM)}

Net Income Margin (NIM) merupakan rasio yang menunjukkan kemampuan manajemen bank dalam mengelola aktiva produktifnya untuk menghasilkan pendapatan bunga bersih. Pendapatan bunga bersih diperoleh dari pemberian kredit atau pinjaman, sementara bank memiliki kewajiban beban bunga kepada deposan. Semakin besar rasio ini maka meningkatkan pendapatan bunga atas aktiva produktif yang dikelola bank sehingga kemungkinan suatu bank dalam kondisi bermasalah semakin kecil. Sehingga dapat disimpulkan bahwa semakin besar perubahan Net Income 
Margin (NIM) suatu bank, maka semakin besar pula profitabilitas bank tersebut, yang berarti kinerja keuangan tersebut semakin meningkat (Sudarmawanti dan Pramono, 2017).

Semakin besar rasio ini maka akan meningkatkan pendapatan bunga atas aktiva produktif yang dikelola bank, sehingga kemungkinan suatu bank dalam kondisi bermasalah semakin kecil dan kinerja perbankan tersebut akan semakin baik (Almilia dan Herdiningtyas, 2005). Lebih lanjut hasil penelitian dari Ali dan Laksono (2017) yang menunjukkan bahwa semakin tinggi net interest margin (NIM) akan berdampak pada peningkatan profitabilitas perbankan yang diproksi dengan return on asset (ROA). Berdasarkan argument tersebut dapat dirumuskan hipotesis kedua $\left(\mathrm{H}_{5}\right)$ sebagai berikut :

\section{Gambar 1 Kerangka Pikir Penelitian}

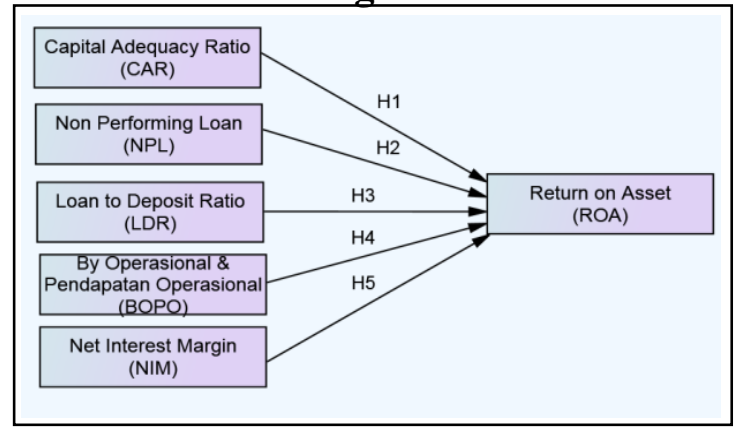

\section{Definisi Konsep dan Operasional} Variabel Variabel - variabel penelitian diukur atau diproksi sebagai berikut :

Tabel 1 :Definisi Konsep dan Operasional Variabel

\begin{tabular}{|c|c|c|}
\hline $\begin{array}{l}\text { Variabel } \\
\text { Penelitian }\end{array}$ & Definisi operasional & Rumus \\
\hline $\begin{array}{l}\text { Return on } \\
\text { asset } \\
\text { (ROA) }\end{array}$ & $\begin{array}{l}\text { Hubungan antara tingkat keuntungan yang } \\
\text { dihasilkan manajemen atas total aset }\end{array}$ & $\mathrm{ROA}=\frac{\text { Laba setelah } p j k}{\text { Total aset }} \times 100 \%$ \\
\hline $\begin{array}{l}\text { Capital } \\
\text { Adequacy } \\
\text { ratio }(\mathrm{CAR})\end{array}$ & $\begin{array}{l}\text { Seberapa jauh seluruh aktiva bank dibiayai } \\
\text { dari dana modal sendiri }\end{array}$ & $\begin{array}{l}\qquad \text { CAR }=\frac{\text { Modal }}{A T M R} \times 100 \% \\
\text { ATMR : Aktiva Tertimbang menurut } \\
\text { Risiko }\end{array}$ \\
\hline $\begin{array}{c}\text { Non } \\
\text { Performing } \\
\text { Loan } \\
\text { (NPL) }\end{array}$ & $\begin{array}{l}\text { Merupakan persentase jumlah } \\
\text { bermasalah terhadap total kredit } \\
\text { disalurkan bank }\end{array}$ & $\mathrm{NPL}=\frac{J m l \text { Kredit Masalah }}{\text { Total Kredit }} \times 100 \%$ \\
\hline $\begin{array}{l}\text { Loan to } \\
\text { Deposit } \\
\text { Ratio } \\
\text { (LDR) }\end{array}$ & $\begin{array}{l}\text { Perbandingan antara total kredit yang diberikan } \\
\text { dengan Total Dana Pihak Ketiga (DPK) yang } \\
\text { dapat dihimpun oleh bank }\end{array}$ & $\mathrm{LDR}=\frac{\text { Total kredit }}{\text { Total DPK }} \times 100 \%$ \\
\hline $\begin{array}{c}\text { Biaya } \\
\text { Operasional } \\
\text { dan } \\
\text { Pendapatan } \\
\text { Operasional } \\
\text { (BOPO) } \\
\end{array}$ & $\begin{array}{l}\text { Rasio untuk mengukur efisiensi dari perbankan } \\
\text { dari memanfaatkan aktiva }\end{array}$ & $\begin{array}{l}\text { BOPO } \\
=\frac{\text { Biaya Operasional }}{\text { Pendapatan Operasional }} \times 100 \%\end{array}$ \\
\hline $\begin{array}{l}\text { Net Interest } \\
\text { Margin } \\
\text { (NIM) }\end{array}$ & $\begin{array}{lcc}\text { Rasio kemampuan manajemen bank } & \text { dalam } \\
\text { mengelola aktiva produktifnya } & \text { untuk } \\
\text { menghasilkan pendapatan bunga bersih } & \end{array}$ & $\begin{array}{l}\text { NIM } \\
=\frac{\text { pendapatan bunga bersih }}{\text { Aktiva Produktif }} \times 100 \%\end{array}$ \\
\hline
\end{tabular}

\section{Populasi dan Sampel}

Populasi dalam penelitian ini adalah seluruh perusahaan dalam seluruh perbankan yang go public di Bursa Efek Indoensia telah terdaftar di Bursa Efek Indonesia 2012 - 2016. Populasi dalam penelitian ini adalah sebanyak 43 perbankan yang tercatat sampai dengan tahun 2016. Pemilihan sampel dilakukan 
dengan menggunakan metode purposive sampling dan menghasilkan sampel 26 bank go public. Pengumpulan data menggunakan panel, sehingga selama 5 tahun periode penelitian jumlah observasi sebanyak 26 perusahaan dan 130 observasi. Pada tahapan untuk memenuhi criteria normalitas data yang tereliminiasi atau terjadi outlier adalah 7 sehingga data yang bisa diolah menjadi 123 observasi.

\section{Jenis dan Metode Pengumpulan Data}

Jenis data yang digunakan dalam penelitian ini adalah data kuantitatif berupa laporan keuangan publikasi tahunan yang diterbitkan oleh Bank Indonesia yang diperoleh dari WEB OJK. Berikutnya adalah dari Indonesia Capital Market Directory (ICMD) dari periode tahun 2012 sampai tahun 2016. Sumber data yang digunakan ini diperoleh melalui penelusuran dari media internet dari www. idx.go.id dan website resmi PT. Bursa Efek Indonesia. Metode pengumpulan data yang digunakan yaitu melalui studi pustaka dari direktori perusahaan go publik dan situs resmi tiap perusahaan. idx.go.id. serta situs - situr resmi lainnya yang dijadikan sampel.

\section{Alat Analisis Data}

\section{Uji Normalitas dan Penyimpangan Asumsi} Klasik

Uji normalitas bertujuan untuk menguji apakah dalam model regresi. variabel pengganggu atau residual memiliki distribusi normal. Seperti diketahui bahwa uji t dan F mengasumsikan bahwa nilai residual mengikuti distribusi normal. Pengujian normalitas menggunakan grafik dan non parametric kolmogorof smirnov (Ghozali, 2018).

Model juga harus terbebas dari penyimpangan asumsi klasik yang terdiri dari uji multikolinearitas ditandai dengan nilai tolerance lebih diatas 0,1 dan VIF dibawah 10 . Penyimpangan uji heteroskedastisitas menggunakan pendekatan grafik scaterplott dan uji glejsyer. Pengujian penyimpangan autokorelasi dengan menggunakan nilai durbin Watson (Ghozali, 2018).

\section{Uji Persamaan Regresi Ganda}

Analisis regresi linier berganda adalah pengaruh secara linier antara dua atau lebih variabel independen dengan satu variabel dependen yang digunakan untuk memprediksi atau meramalkan suatu nilai variabel dependen berdasarkan variabel independen. Sebelum melakukan estimasi yang tidak biasa dengan analisis regresi, perlu dilakukan uji t dan uji Fit data yaitu pengujian antar variabel bebas supaya tidak terjadi multikolinieritas, heteroskedastisitas, normalitas, dan autokorelasi (Astohar, 2013).

Persamaan regresi pada penelitian ini terdapat dua model. yaitu sebagai berikut: $\mathrm{Y}=\mathrm{a}+\mathrm{b}_{1} \mathrm{X}_{1}+\mathrm{b}_{2} \mathrm{X}_{2}+\mathrm{b}_{3} \mathrm{X}_{3}+\mathrm{b}_{4} \mathrm{X}_{4}+\mathrm{b}_{5} \mathrm{X}_{5}$

Dimana :

$\mathrm{X}_{1}$ : ukuran perusahaan

$\mathrm{X}_{3}$ : profitabilitas

Y : profitabilitas perbankan

\section{Koefisien Determinasi}

Koefisien determinasi pada intinya untuk mengukur seberapa jauh kemampuan model dalam menerangkan variasi variabel dependen. Koefisien determinan pada penelitian ini digunakan untuk melihat berapa persen dari variasi variabel terikat dijelaskan variabel bebas. (Ghozali, 2018).

\section{HASIL DAN PEMBAHASAN Analisis Deskriptif}

Deskripsi tentang rasio-rasio penelitian yang berupa capital adequacy ratio yang rataratanya adalah sebesar 18,59. Berdasarkan rata - rata, perbankan masuk dalam kategori yang sehat. Berdasarkan data yang diperoleh capital adequacy ratio (CAR) terendah selama periode penelitian adalah sebesar 10,44 yaitu Bank Mayapada International, Tbk pada tahun 2014 dan yang tertinggi adalah pada sebesar 45,52 pada Bank Woori Saudara Indonesia, Tbk pada tahun 2012. 
Pada variabel non performing loan (NPL) ini menunjukkan bahwa berdasarkan rata - rata perbankan masuk dalam kategori yang sehat atau bagus, hal ini ditandai dengan rata - rata non performing loan (NPL) masih dikisaran $1,99 \%$ (sehat masih dibawah $5 \%$ ). NPL terendah selama periode penelitian adalah sebesar 0,002 pada Bank Of China, Tbk pada tahun 2012 dan tertinggi adalah sebesar 4,86 pada Bank BRI Syariah pada tahun 2015.

Pada variabel loan to deposit ratio (LDR) ini menunjukkan bahwa berdasarkan rata - rata perbankan masuk dalam kategori yang kurang bagus, hal ini ditandai dengan rata - rata loan to deposit ratio $(L D R)$ dikisaran dibawah $90 \%$ (sehat antara $90 \mathrm{sd} 110$ ). loan to deposit ratio (LDR) terendah selama periode penelitian adalah sebesar 52,39 pada Bank Mega, Tbk pada tahun 2012 dan tertinggi adalah sebesar 169,76 pada Bank Bank Of China 2016.

Pada variabel biaya operasional dan pendapatan operasional (BOPO) ini menunjukkan bahwa berdasarkan rata - rata perbankan masuk dalam kategori yang kurang bagus, hal ini ditandai dengan rata - rata biaya operasional dan pendapatan operasional (BOPO) dikisaran dibawah $90 \%$ yaitu sebesar $80,31 \%$ (sehat antara 90 sd 110). Biaya operasional dan pendapatan operasional (BOPO) terendah selama periode penelitian adalah sebesar 33,28 pada Bank Woori Saudara Indonesia, Tbk pada tahun 2013 dan tertinggi adalah sebesar 108,03 pada Bank QNB Kesawan, Tbk pada tahun 2012.

Pada variabel net interest margin (NIM) ini menunjukkan bahwa berdasarkan rata - rata perbankan masuk dalam kategori yang sehat atau bagus, hal ini ditandai dengan rata - rata net interest margin (NIM) masih dikisaran 5,45 $\%$ (sehat lebih dari $5 \%$ ). net interest margin (NIM) terendah selama periode penelitian adalah sebesar 1,49 pada Bank of China pada tahun 2012 dan tertinggi adalah sebesar 13,12 pada Bank BTPN pada tahun 2012 juga.

Pada variabel (ROA) ini menunjukkan bahwa berdasarkan rata - rata perusahaan masuk dalam kategori yang kurang bagus, hal ini ditandai dengan rata - rata (ROA) masih dikisaran 2,07 \% (sehat lebih dari 1,5\%). (ROA) terendah selama periode penelitian adalah sebesar - 0,8 pada Bank QNB Kesawan, Tbk pada tahun 2012 dan tertinggi adalah sebesar 5,2 pada Bank Rakyat Indonesia, Tbk pada tahun 2012.

\section{Uji Penyimpangan Asumsi Klasik}

Model penelitian pada awalnya tidak terdistribusi secara normal, diindikasikan ada data yang ekstrim. Direkomendasikan untuk membuang data sebanyak 7 observasi. Setelah 7 data dikeluarkan model terdisitribusi secara normal, yang ditandai dengan grafik normal P - P Plot Regression yang titik-titik pada grafik menyebar disekitar garis diagonal, serta penyebarannya mengikuti arah garis diagonal. Selain itu pada grafik Histogram yang menunjukkan sebaran data mendekati garis normal. Untuk memperkuat analisis digunakan metode statistik yang ditandai dengan nilai uji kolmogorof smirnov sebesar 0,957 (diatas 0,05).

\section{Terbebas}

penyimpangan

Multikolinearitas, yaitu dibuktikan dengan nilai tolerance diatas 0,1 yaitu masing masing sebesar 0,716;0,855;0,712 ; 0,709 dan 0,945 dan nilai variance inflation factor (VIF) dibawah 10 yaitu masing masing 1,$396 ; 1,170 ; 1,405 ; 1,410$ dan 1,058. Selain itu nilai koefisien korelasi antar variabel bebas adalah lemah yaitu sebesar - 0,029;0,207; -0,003;0,154;0,$157 ; 0,176 ;-0,290 ;-0,354 ; 0,288$ dan 0,217 yang mana nilai tersebut masih dibawah 0,7 .

Terbebas

penyimpangan heteroskedastisitas yang ditandai grafik sccaterplot (lampiran) tidak membentuk pola khusus atau gambarnya menyebar. serta terbebas dari penyimpangan autokorelasi, yaitu ditandai dengan nilai 
durbin Watson sebesar 1,731 yang mana nilai tersebut masuk dalam areal tidak terjadi autokorelasi.

\section{Uji Fit Data}

Hasil uji fit data diperoleh nilai $F$ hitung sebesar 295,388 serta nilai probabilitas sebesar 0,000. Hasil perbandingan menunjukkan bahwa nilai probabilitas $(0,000)<\alpha(0,05)$ dan $\mathrm{F}$ hitung lebih besar dari $F$ tabel $(295,388>2,45)$. Sehingga dapat dikatakan bahwa permodelan yang dibangun memenuhi kriteria fit.

\section{Persamaan Regresi Berganda dan Pengujian Hipotesis}

Berdasarkan tabel diatas diperoleh persamaan regresi sebagai berikut :

ROA $=8,981-0,034$ CAR - 0,021 NPL 0,010 LDR - 0,084 BOPO + 0,253 NIM

Nilai konstanta pada penelitian ini diperoleh nilai 8,981 yang dapat diartikan bahwa tanpa adanya perubahan dari variabel bebas atau variabel CAR, NPL, LDR, BOPO dan NIM maka profitablitas bank (return on asset) pada perbankan mengalami peningkatan.

Capital adequacy ratio (CAR) perbankan yang go publik di Bura Efek Indonesia mempunyai pengaruh negatif terhadap profitabilitas bank dengan koefisien regresi sebesar - 0,034. Hal ini dapat diartikan setiap adanya peningkatan Capital adequacy ratio (CAR) maka profitabilitas perbankan yang go publik di Indonesia akan mengalami penurunan, atau sebaliknya. Hipotesis diterima, karena dibuktikan dengan nilai probabilitas (sig) sebesar 0,000 yang mana nilai tersebut masih di bawah 0,05 .

Hipotesis $1\left(\mathrm{H}_{1}\right)$ yang diajukan adalah capital adequacy ratio (CAR) pada Perbankan berpengaruh negatif dan signifikan terhadap profitabilitas perbankan.
Hasil pengujian menunjukkan bahwa hipotesis $1\left(\mathrm{H}_{1}\right)$ terbukti signifikan, hal ini dapat ditunjukkan dengan nilai $\mathrm{t}$ hitung sebesar - 4,670 yang kurang dari t tabel ($1,96)$ serta nilai probabilitas $(0,000)<\alpha$ $(0,05)$. Sehingga dapat dijelaskan bahwa capital adequacy ratio (CAR) Perbankan terbukti berpengaruh negatif dan signifikan terhadap profitabilitas perbankan atau semakin besar capital adequacy ratio (CAR) maka akan meningkatkan profitabilitas perbankan yang go publik di Indonesia.

Non performing loan (NPL) perbankan yang go publik di Indonesia tidak terbukti mempunyai pengaruh negatif dan signifikan terhadap profitabilitas perbankan (ROA) dengan koefisien regresi sebesar - 0,021. Hal ini dapat diartikan bahwa setiap peningkatan Non performing loan (NPL) maka tidak secara langsung profitabilitas perbankan (ROA) yang go publik di Indonesia mengalami penurunan. Hipotesis ditolak, karena dibuktikan dengan nilai probabilitas (sig) sebesar 0,443 yang mana nilai tersebut di atas 0,05 .

Hipotesis $2\left(\mathrm{H}_{2}\right)$ yang diajukan adalah non performing loan (NPL) berpengaruh negatif dan tidak signifikan terhadap profitabilitas perbankan (ROA). Hasil pengujian menunjukkan bahwa hipotesis $2\left(\mathrm{H}_{2}\right)$ tidak terbukti, hal ini dapat ditunjukkan dengan nilai t hitung sebesar $-0,770$ yang lebih dari dari - $\mathrm{t}$ tabel $(-1,960)$ serta nilai probabilitas $(0,443)>$ $\alpha(0,05)$. Sehingga dapat dijelaskan bahwa non performing loan (NPL) tidak terbukti berpengaruh negatif dan signifikan terhadap profitabilitas perbankan atau semakin tinggi rasio NPL maka tidak secara langsung menurunkan profitabilitas perbankan, hal ini ditandai dengan hipotesis yang tidak terbukti.

Loan to deposit ratio (LDR) perbankan yang go publik di Indonesia mempunyai pengaruh negatif terhadap profitabilitas perbankan dengan koefisien regresi sebesar 0,010. Hal ini dapat diartikan bahwa setiap 
peningkatan loan to deposit ratio (LDR) maka profitabilitas perbankan yang go publik di Indonesia mengalami penurunan. Hipotesis diterima, karena dibuktikan dengan nilai probabilitas (sig) sebesar 0,000 yang mana nilai tersebut di bawah 0,05 .

Hipotesis $3\left(\mathrm{H}_{3}\right)$ yang diajukan adalah loan to deposit ratio (LDR) pada perbankan berpengaruh negatif dan signifikan terhadap profitabilitas perbankan. Hasil pengujian menunjukkan bahwa hipotesis $3\left(\mathrm{H}_{3}\right)$ terbukti, hal ini dapat ditunjukkan dengan nilai $t$ hitung sebesar - 5,109 yang kurang dari - $\mathrm{t}$ tabel ($1,960)$ serta nilai probabilitas $(0,000)<\alpha$ $(0,05)$. Sehingga dapat dijelaskan bahwa loan to deposit ratio (LDR) terbukti berpengaruh negatif dan signifikan terhadap profitabilitas perbankan atau semakin tinggi loan to deposit ratio $(L D R)$ maka akan akan berakibat pada penurunan profitabilitas perbankan.

Biaya operasional dan pendapatan operasional (BOPO) perbankan yang go publik di Indonesia mempunyai pengaruh negatif terhadap profitabilitas perbankan dengan koefisien regresi sebesar $-0,084$. Hal ini dapat diartikan bahwa setiap peningkatan Biaya operasional dan pendapatan operasional (BOPO) maka profitabilitas perbankan yang go publik di Indonesia mengalami penurunan. Hipotesis diterima, karena dibuktikan dengan nilai probabilitas (sig) sebesar 0,000 yang mana nilai tersebut di bawah 0,05 .

Hipotesis $4\left(\mathrm{H}_{4}\right)$ yang diajukan adalah Biaya operasional dan pendapatan operasional (BOPO) pada perbankan berpengaruh negatif dan signifikan terhadap profitabilitas perbankan. Hasil pengujian menunjukkan bahwa hipotesis $4\left(\mathrm{H}_{4}\right)$ terbukti, hal ini dapat ditunjukkan dengan nilai $\mathrm{t}$ hitung sebesar 29,222 yang kurang dari - $t$ tabel $(-1,960)$ serta nilai probabilitas $(0,000)<\alpha(0,05)$. Sehingga dapat dijelaskan bahwa Biaya operasional dan pendapatan operasional (BOPO) terbukti berpengaruh negatif dan signifikan terhadap profitabilitas perbankan atau semakin tinggi nilai BOPO maka akan berakibat pada penurunan profitabilitas perbankan.
Net interest margin (NIM) perbankan yang go publik di Indonesia mempunyai pengaruh positif terhadap profitabilitas perbankan dengan koefisien regresi sebesar 0,253 . Hal ini dapat diartikan bahwa setiap peningkatan net interest margin (NIM) maka profitabilitas perbankan yang go publik di Indonesia mengalami peningkatan. Hipotesis diterima, karena dibuktikan dengan nilai probabilitas (sig) sebesar 0,000 yang mana nilai tersebut di bawah 0,05 .

Hipotesis $5\left(\mathrm{H}_{5}\right)$ yang diajukan adalah net interest margin (NIM) pada perbankan berpengaruh positif dan signifikan terhadap profitabilitas perbankan. Hasil pengujian menunjukkan bahwa hipotesis $5\left(\mathrm{H}_{5}\right)$ terbukti, hal ini dapat ditunjukkan dengan nilai t hitung sebesar - 17,440 yang kurang dari - $t$ tabel ($1,960)$ serta nilai probabilitas $(0,000)<\alpha$ $(0,05)$. Sehingga dapat dijelaskan bahwa net interest margin (NIM) terbukti berpengaruh negatif dan signifikan terhadap profitabilitas perbankan atau semakin tinggi nilai net interest margin (NIM) maka akan berakibat pada peningkatan profitabilitas perbankan.

\section{Koefisien Determinasi}

Berdasarkan hasil perhitungan diperoleh nilai koefisien determinasi ( $R$ Square) sebesar 0,923. Hal ini berarti besar variasi variabel profitabilitas perbankan (ROA) yang go publik di Indonesia yang dapat diterangkan oleh variasi variabel ukuran perusahaan capital adequacy ratio (CAR), non performing loan (NPL), loan to deposit ratio $(L D R)$, biaya operaional dan pendapatan operasional (BOPO), net interest margin (NIM) adalah sebesar $92,3 \%$, sedangkan sisanya sebesar 7,7 $\%$ dipengaruhi oleh variabel lain di luar model penelitian.

\section{PENUTUP}

1. Capital adequacy ratio (CAR) terbukti mempunyai pengaruh yang negatif dan signifikan terhadap profitabilitas perbankan ( $\mathrm{H}_{1}$ terbukti). 
2. Non performing loan (NPL) terbukti mempunyai pengaruh yang negatif dan tidak signifikan terhadap profitabilitas perbankan $\left(\mathrm{H}_{2}\right.$ terbukti).

3. Loan to deposit ratio (LDR) terbukti mempunyai pengaruh yang negatif dan signifikan terhadap profitabilitas perbankan ( $\mathrm{H}_{3}$ terbukti).

4. Biaya operaional dan pendapatan operasional (BOPO) terbukti mempunyai pengaruh yang negatif dan signifikan terhadap profitabilitas perbankan $\left(\mathrm{H}_{4}\right.$ terbukti).

5. Net interest margin (NIM) terbukti mempunyai pengaruh yang positif dan signifikan terhadap profitabilitas perbankan ( $\mathrm{H}_{5}$ terbukti).

6. Besar variasi variabel struktur modal pada perbankan yang go publik di Indonesia yang dapat diterangkan oleh variasi variabel capital adequacy ratio (CAR), non performing loan (NPL), loan to deposit ratio (LDR), biaya operaional dan pendapatan operasional (BOPO), net interest margin (NIM) adalah sebesar 92,3 $\%$.

\section{Kelemahan dan Agenda Mendatang}

1. Penelitian hanya pada perbankan yang go public di Bursa Efek Indonesia atau tidak memasukkan perbankan yang lainnya

2. Penelitian mendatang mengarahkan pada obyek penelitian yang lebih luas dengan mengambil obyek - obyek sector bank lainnya misalnya pada Bank Perkreditan Rakyat, Bank BUMN ataupun yang lainnya.

3. Penelitian ke depan perlu dengan menambah atau membuat model structural (bertingkat) dapat berpengaruh terhadap profitabilitas perbankan.

\section{DAFTAR PUSTAKA}

Achmad, S. 2003, Ekonomi Perbankan, STIE Gunadarma, Jakarta.

Ahmad Buyung Nusantara, 2009, "Analisis Pengaruh NPL, CAR, LDR, dan BOPO Terhadap Profitabilitas Bank", Tesis, Universitas Diponegoro.

Ali, Muhammad dan Laksono, Roosaleh., 2017, Pengaruh Net Interest Margin (NIM), Biaya Operasional Terhadap Pendapatan Operasional BOPO), Loan to Deposit Ratio (LDR) dan Non Performing Loan (NPL)Terhadap s (ROA), Jurnal Riset Akuntansi Dan Keuangan, Vol.5 No.2, Bandung.

Apsari. Idha Ayu, Dwiatmanto dan Devi Farah Azizah., 2015., Pengaruh Return On Equity. Net Profit Margin. Debt to Equity Ratio. dan Longterm Debt to Equity Ratio terhadap Price Book Value (Studi pada Perusahaan Sub Sektor Makanan dan Minuman yang Terdaftar di Bursa Efek Indonesia Periode Tahun 20102013)., Jurnal Administrasi Bisnis (JAB), Vol.27 No.2 Oktober 2015

Astohar, 2013, Statistika Bisnis Kasus dan Solusi, Penerbit Duta Nusindo, Semarang.

Astohar, 2016, Pengaruh Capital Adequacy Ratio (Car) Dan Financing To Deposit Ratio Terhadap Profitabilitas Perbankan Syariah Di Indonesia Dengan Inflasi Sebagai Variabel Pemoderasi., Among Makarti Vol.9 No.18, Desember 2016

Bernardin, Deden Edwar Yokeu., 2016., Pengaruh CAR dan LDR terhadap Return on Assets, Ecodemica, Vo.4, No 2.

Dwi Indah Putrianingsih, Arief Yulianto, 2016, Pengaruh Non Performing Loan (NPL) dan Capital Adequacy Ratio (CAR) terhadap Profitabilitas, Management Analysis Journal Vol.5 No.2 
Defri, 2012, Pengaruh Capital Adequacy Ratio (CAR), Likuiditas Dan Efisiensi Operasional Terhadap Profitabilitas Perusahaan Perbankan Yang Terdaftar Di BEI, Jurnal Manajemen, Vol.1, No.1, September 2012

Ghozali, Imam, 2007, Manajemen Risiko Perbankan Pendekatan VaR, Badan Penerbit Universitas Diponegoro, Semarang.

Ghozali, Imam, 2018, Aplikas Analisis Multivariate dengan Program IBM SPSS 25, Edisi 9, Badan Penerbit Universitas Diponegoro, Semarang.

Husnan Suad dan Pudjiastut., 2012, Dasar Dasar Manajemen Keuangan, UPP STIM YKPN, Edisi 6, Yogyakarta.

Khoirunnisa, Hani Maulida, Rodhiyah, Saryadi, 2016, Pengaruh Capital Adequacy Ratio (CAR), Loan To Deposit Ratio (LDR) dan $B O P O$ terhadap Profitabilitas (ROA dan $R O E)$ Bank Persero Indonesia yang Dipublikasikan Bank Indonesia Periode 2010 - 2015, Jurnal Administrasi Bisnis, Semarang.

Latifah, Nurul Maulidya, Rodhiyah, Saryadi. 2012, Pengaruh Capital Adequacy Ratio (CAR), Non Performing Loan (NPL) dan Loan to Deposit Ratio (LDR) terhadap (ROA) (Studi kasus pada Bank Umum Swasta Nasional Devisa Go Public di Bursa Efek Indonesia Periode 20092010)., Jurnal Ilmu Administrasi Bisnis., Semarang.

Matindas, Anggria Maya, Pangemanan, Sifrid S. dan David P.E. Saerang, 2013, Pengaruh Capital Adequacy Ratio (CAR), BOPO dan Non Performing Loan (NPL) terhadap Kinerja Keuangan Perbankan di Indonesia, Jurnal Unsrat.

Moslem, Orchidia Seta dan M. Chabachib, 2016., Analisis Faktor-Faktor Yang Berpengaruh Terhadap Profitabilitas Perbankan (Studi Perbandingan Bank
Devisa dan Bank Non Devisa Di Indonesia Periode 2010-2014), Jurnal Bisnis dan Manajemen., Vol.4 No.4

Mudrajad Kuncoro dan Suhardjono, 2002, Manajemen Perbankan Teori dan Aplikasi, BPFE UGM, Yogyakarta.

Olarewaju, Odunayo M. dan Adeyemi, 2015, Oluwafeyisayo K., Causal Relationship between Liquidity and Profitability of Nigerian Deposit Money Banks., International Journal of Academic Research in Accounting, Finance and Management Sciences, Vol.5, No.2

Pranata, A.A Alit Wahyu Dwi, 2015, Pengaruh Capital Adequacy Ratio, Loan To Deposit Ratio dan Ukuran Perusahaan pada Profitabilitas Bank di Bursa Efek Indonesia., E-jurnal Akuntansi Universitas Udayana Vol.11, No.1

Rahmani, Nur Ahmadi Bi, 2017, Analisis Pengaruh Capital Adequacy Ratio (CAR) dan Financing to Deposit Ratio (FDR) terhadap (ROA) dan Return On Equity (ROE) Pada Perusahaan Bank Umum Syariah di Indonesia., Jurnal Human Falah., Vol.4 No.4. Yogyakarta.

Samsara, Essamaski, 2016, Analisis Pengaruh Capital Adequacy Ratio (CAR), non performing Loan (NPL) dan Loan to Deposit Ratio (LDR) terhadap Return on Asset (ROA) pada kelompok Bank Pembangunan Daerah dan Bank Non Devisa di Indonesia, Indonesia Banking School.

Simanjuntak, Jontro, 2016, Pengaruh Capital Adequacy Ratio (CAR), Loan to Deposit Ratio (LDR) dan Non Performing Loan (NPL) Terhadap $s$ (ROA) Pada Sektor Perbankan di Bursa Efek Indonesia., Jurnal Bisnis dan Manajemen Vol.2 No.2.

Sudarmawanti, Erna dan Pramono, Joko, 2017, Pengaruh CAR, NPL, BOPO, NIM dan LDR terhadap ROA (Studi kasus pada 
Bank Perkreditan Rakyat di Salatiga yang terdaftar di Otoritas Jasa Keuangan Tahun 2011-2015), Among Makarti, Vol.10, No.19.

Veithzal Rivai, Andria Permata Veithzal dan Ferry N., Idroes, 2007, Bank and Financial Institution Mangement, PT. Raja Grafindo Persada, Jakarta. 